\title{
Opportunities for Practicing Sustainable Building Construction in Kurdistan Region, Iraq
}

*MA. LAWAND WIRYA SHAWKAT ${ }^{1}$, Ph.D. Candidate SALAR SALAH MUHY AL-DIN ${ }^{2}$, Dr. DUSKO KUZOVIC ${ }^{3}$

1 Department of Architecture, Near East University, Turkey

${ }^{2}$ Department of Architecture, Girne American University, Turkey

${ }^{3}$ Department of Architecture, University of East Sarajevo, Bosnia and Herzegovina

E mail: lawandw@gmail.com ,E mail: salars.muhyaldin@yahoo.com,E mail: dusko.kuzovic@gmail.com

This work is licensed under a Creative Commons Attribution NonCommercial - NoDerivs 4.0. "CC-BY-NC-ND"

\begin{tabular}{l} 
A R T I C L E I N F O: \\
\hline Article history: \\
Received 30 July 2017 \\
Accepted 20 August 2017 \\
Available online 17 September \\
2017 \\
\hline Keywords: \\
Sustainable \\
Construction; \\
Green Rating Systems; \\
Sustainable \\
Construction Barriers; \\
Kurdistan region of \\
Republic of Iraq
\end{tabular}

\section{A R T I CLEINF O:}

Accepted 20 August 2017

2017

Green Rating Systems:

Construction Barriers;

Republic of Iraq

\begin{abstract}
A B S T R A C T
Construction sector of Kurdistan region of Republic of Iraq has witnessed a huge development in construction sector last ten years. However, there are lack of awareness and legislation regarding the sustainable construction in buildings sector. The aim of the paper is to find the required mechanism to introduce sustainable practice and implement sustainable construction in the buildings construction sector at Northern Iraq. The main objectives in this study are identifying the barriers in sustainable construction at Northern Iraq and investigate the law and regulations in dealing with these barriers.
\end{abstract}

JOURNAL OF CONTEMPORARY URBAN AFFAIRS (2018) 2(1), 96-101. https://doi.org/10.25034/ijcua.2018.3665

\section{Introduction}

The necessity to overcome the global warming and climatic changes, which the world facing it in $21^{\text {st }}$ century, requires the action towards sustainability are crucial subject nowadays. Growth population and expanding of urbanization will continue increasing the buildings construction. In the same context, the needs for the safe and good life of future generations are also important.

To reach this goal there is vital requirement to control urban planning, design and construction. Thus, sustainability in design and construction became crucial for the storing of natural resources for next generations. United Nations World Commission on Environment and
Development (UNWCED), defined Sustainability was defined as that which

"meets the needs of the present without compromising the ability of future generations to meet their own needs" (1987), (Al Surf, 2014).

*Corresponding Author:

Department of Architecture, Near East University, Turkey

E-mail address: lawandw@gmail.com 


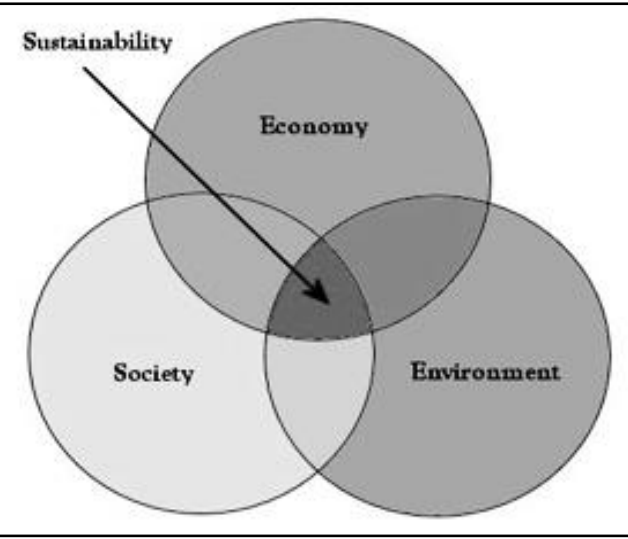

Figure 1. Three main aspects of sustainability (from Juneau Commission on Sustainability)

Sustainable development and construction of the buildings are directly affecting one another, as Section 7.67 of the United Nations' Agenda 21 states:

"The activities of the construction sector are vital to the achievement of the national socio-economic development goals of providing shelter, infrastructure and employment. However, they can be a major source of environmental damage through depletion of the natural resource base, degradation of fragile eco-zones, chemical pollution and the use of building materials harmful to human health"(UN Agenda 21, 2004).

Sustainability consists of three main aspects, the interrelation of them creates the sustainability. Sustainable development recognized in three terms, that are environmental protection, economic growth, and social development (Adams, 2006). These aspects should be available in order to achieve sustainability in any field. See figure ' 2 '.

Generally sustainable buildings supposed to achieve the three main aspects of sustainability: Environmental sustainability, economic sustainability and Social sustainability (McConville, 2006). Table ' 1 ', shows the main factors to achieve sustainability in the buildings considering the three aspects of sustainability.

Constructions, involves into socio-economic fields and environmental field as well, through making remarkable use of natural resources and increase the generation of greenhouse gasses through buildings (Asif et al., 2005). According to Zainulabidin and Pasquire, (2005), the main principles in sustainable building are to implement the safety and comfort to occupants as well as the surrounding environment and society.

\section{Documents and Discussion}

\subsection{Kurdistan Region (Northern Iraq) Of Republic Of Iraq}

Northern Iraq is a federal part in federal state of Iraq. The region bordered by Turkey from the north, by Iran from the East, by Syria from the west and from the south by the rest of Iraq. The capital of the region is 'Erbil'. The population of Northern Iraq region is 5.2 million. It consist of Three governorates of Erbil, Slemani (including administration of Garmian), Duhok, and later in 2014 the forth governorate added to the region named Halabja.

Those four governorates cover approximately 40,000 square kilometers which is larger than the Netherlands, Bahrain, and four times the area of Lebanon. This include the governorates administered by KRG, but does not contain areas of Kurdistan outside of KRG administration, such as Kirkuk (Soderberg, and Phillips, 2015).

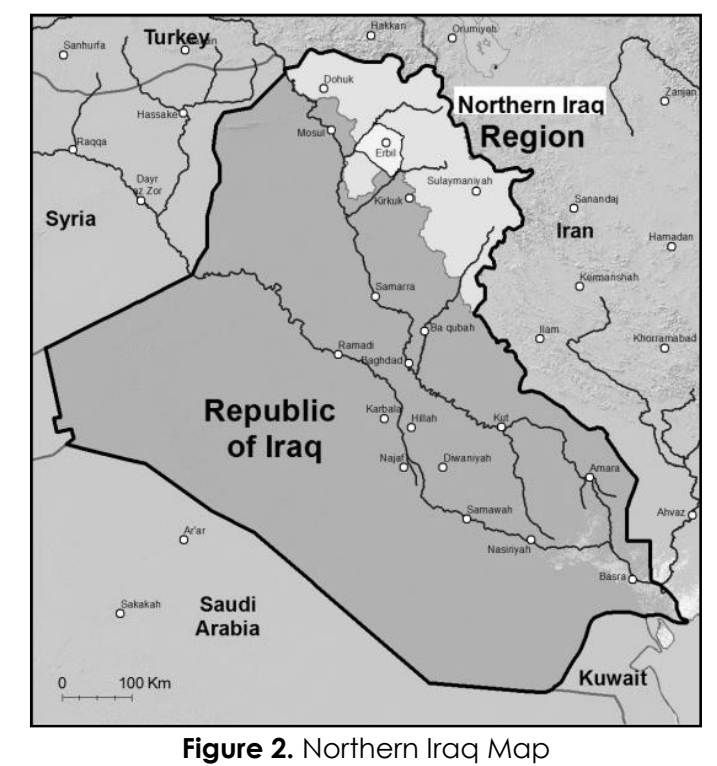

Source: (http://www.iran-daily.com/News/155384.html)

\subsection{Building Construction In Northern Iraq Region}

The construction sector is a big part of the Northern Iraq Region's economy because of its influence on other sectors. The span of the development market is evaluated at $\$ 2.8$ billion, with $95 \%$ of the market controlled by Turkish construction companies. According to ECU (Erbil Contractors' Union), the total numbers of construction contractors in the region is estimated by 2,500 contractors, there are 59 foreign Members out of that, 51 of them are Turkish and 8 are Iranian. According to, 'the Turkish Daily News' mentioned that the total numbers of the Turkish contracting companies are estimated by 634 companies working in 
Northern Iraq, (USAID, 2008; Alizadehsalehi et al., 2016).

Building costs rising progressively in Northern Iraq, because of the rising of prices for fuel, materials, as well as labors. Since 2000 , steel-bars have increased from $\$ 200$ per ton to reach $\$ 700-\$ 800$ per ton in 2008. Also, the cost of cement increased from $\$ 25$ per ton to $\$ 125-\$ 150$ per long ton. According to the Contractor Union in Northern Iraq asserted, that the construction costs have increased 6 time over 10 years (USAID, 2008).

\subsection{The Elements of Sustainability in Building Construction}

Previously many institutes and researchers such as; UNEP (2003), Huovila and Richter (1997), have viewed sustainable construction as an environmental issue. Consequently, this made many researchers to consider sustainable construction as a good environmental management, but this understanding of sustainable construction has been changed over the years. In the beginning they focus on the resources depletion subject through energy consumption, and reducing the impact on environment.

Therefore the technical solutions through building material, and design concept were the goals (Sjostrom and Bakens, 1999). When sustainable construction have been understood as application for the principles of the sustainable development in construction sector, then it is generally accepted that similar to SD, sustainable construction addressed the three aspects of environmental, social and economic elements. Hence, and according to Gunatilake (2013), some of extra components have been considered by several researchers in different studies. These elements are:

1. Environmental/ Ecological/ Biophysical

2. Social

3. Economical.

4. Institutional.

5. Legal.

6. Political.

7. Cultural.

8. Technical.

9. Managerial.

10. Community.

11. Moral.

Some other researchers use additional elements, such as Liu, (2006) who used two different components, socio-economic; which refers to the construction process participants behavior in procuring assembled resources) and socioenvironmental, which refers to the social and environmental aspects. These two elements used in place of the more common three aspects (environmental, social, and economic)

\subsection{Green Building and Green Building Rating System}

There are many definitions for 'Green Building'. Green Building can be defined as, the building whose construction and operation lifetime assure the most efficient and least degradation use of land, efficient use of water, energy and resources, and offer the healthiest environment (Gunatilake, 2013). The best design solution is that simulate all of the natural systems and conditions before site development and after the development, effectively.

Green building were described according to, Office of Federal Environmental Executive as; the process or application that increase the efficiency within buildings and their sites in usage of energy, water and material, and the buildings which reducing the impacts on the environment and human health. This could be achieved through better sitting, design, construction, use, maintenance, and demolishing (U.S. Green Building Council, 2006).

Different terms were used by the researchers to address the same meaning. For example, Robichaud and Anantatmula (2011) mentions that green building is also giving the meaning of sustainable construction, and 'High performance building', or 'Sustainable building'. In general the sustainable construction leads to achieve green building in the same time high performance and sustainable one.

Rating system is the building environmental performance assessment system; the purpose of this assessment system is to measure the environmental performance of the buildings. In UK In 1990, the Building Research Establishment, LLC (BRE) made an environmental evaluation technique (BREEAM), (BREEAM, 2009). Fourteen countries in 1996; Canada, Austria, Denmark, Finland, Poland, France, Japan, Norway, Sweden, Germany, Switzerland, Netherlands, United States and United Kingdom, started to develop technique known as the 'Green Building Challenge'. The aim was to develop and apply a system for measuring the performance in the buildings environmentally and through energy issues. The Green Building Challenge proceeded with its advancement through 2000 to 2005, and come about of the advancement was the' GBTool'. It is an apparatus to help in the environmental assessment of buildings. 'Green Building Challenge' became presently the 
'Sustainable Building Challenge' and proceeds to develop the process about environmental building implementation performance and green building design (iiSEBE, 2009). Many other green rating systems have been created in many countries based on BREEAM, based on the needs of a country through environmental perspective. Rating systems evolved in coming years according to two main factors; user feedback and the technology development, in order to enhance the achievement of buildings in term of environmental level. Green rating systems started as a voluntary measure of environmental performance. Nowadays certification is recommended for buildings in many countries. Currently, there are fifteen rating systems that give certifications to buildings performance around the world, see figure ' 3 '. Only three systems of them are using currently for structures outside of their nations of origin, there are; Leadership in Energy and Environmental Design (LEED), BREEAM, and Green Globes.

Figure 3. Rating system based on their development timeline.

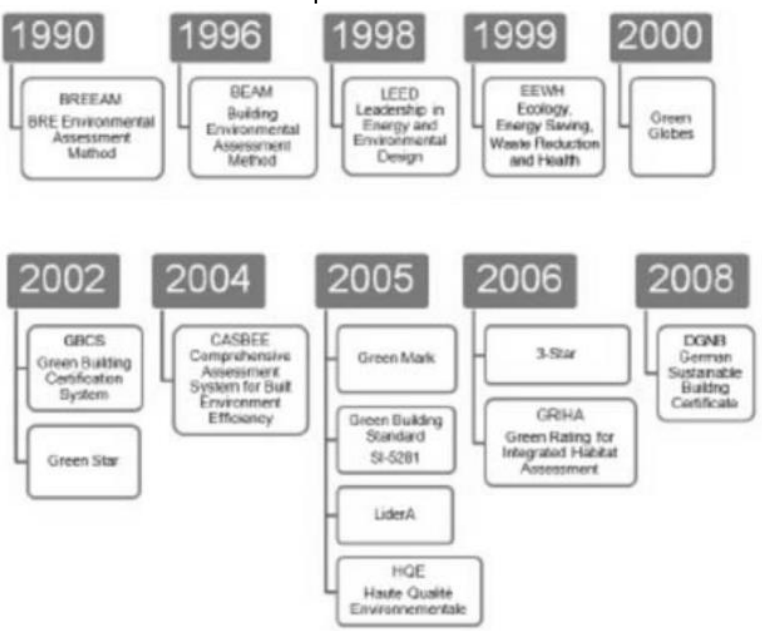

Source: [Retrieved] on 3rd of March, 2017 from IFMA Environmental Stewardship and Sustainability Strategic Advisory Group (ESS SAG):

http://cdn.ifma.org/sfcdn/membership-documents/greenrating-systems-htg-final.pdf

\subsection{Barriers To Achieve Sustainable Construction Practices}

There are several factors that could make barriers to achieve sustainable construction, and one of the main those factors are cost factor. In common sustainable buildings cost more than ordinary buildings through initial cost by around $2 \%$ to $7 \%$ (Castillo and Chung, 2005). Some projects can recover that extra cost through short time pay back. Awareness about sustainability and teaching stakeholders to think about value more than cost and think in the direction of longterm instead of short- term could overcome the problem.

The political factor is another important factor, which refers to the deficiency in government legislations or support, lack of building construction specification and codes on sustainability (Rydin, et al., 2006). The successful sustainable construction is highly depending on the government commitment in addition to the regulation and legislation. There are many benefits regarding sustainable construction, hence, governments should encourage and incorporate sustainable construction practices in construction projects to stimulate private sectors and individuals to act in the same way (Dzokoto and Dadzie, 2013).

The awareness and knowledge about sustainability have significant impact on the implementation of sustainable construction (Häkkinen, and Belloni, 2011). This factor refers to the shortage of professionals or professional knowledge, also un- awareness of clients to the benefits of applying the sustainability, or the misunderstanding about sustainability. In additional to that, shortage in knowledge about sustainable design. Williams and Dair (2007), in their research addressed that the hindrance front of applying sustainable construction is a shortage in stockholders awareness about sustainable measures that fall within their career field.

Socio-Cultural factor is one of the barrier fronts of implementation sustainable construction. This can be realized through the deficiency in the demand on sustainable products by the client. This refers to the society resistance to change the traditional way or concepts in construction ways (Williams and Dair, 2007).

The technical factor is one of the barriers which have significant effects on sustainable construction. The lack of sustainable materials or eco-friendly materials, also, the shortage of sustainable measurement tools, lack in technical potentials, skills and labor experience shortages (Nelms, et al., 2005).

The leadership and management factor is another barrier in the way of achieving sustainable construction. It affects the construction industry and individual organizations to implement successful creative strategies, (Osaily, 2010).

\section{Conclusion}

The study identified the most important barriers front of the sustainable construction in the 
buildings based on literature review and deep theoretical analysis. The literature review came out with international list of barriers that could be hinders front of the sustainability in building construction sector. Also, to examine the ability of applying LEED green rating system in Northern Iraq as one of the international standards, and how it could be useful. The Author employed that to apply it in a questionnaire in order to get the opinion of professional people in this field or to find other barriers, which could be limited to the region of the study out of the international barriers. In spite of the lack of the professionals in the field of sustainable building construction and design in the region of the study, but the Author could get 20 participants to participate in a questionnaire, which had been conducted in the Northern Iraq. The result of the questionnaire was compared with the obtained data through theoretical analysis, and the results demonstrate the following;

1. The most important barriers in sustainable building construction is the Initial cost and lack of regulation and legislations regarding the issue of sustainability in the construction specifications.

2. The international barriers in the sustainable construction in all around the world is the same barriers in the region of the study.

3. LEED green rating system is possible to be employed as sustainable rating system in construction projects, at Northern Iraq, but with some developments to be adapted to the climatic characteristic of the region and some modification to harmonize the socio-cultural needs.

4. The study demonstrated that the most prior and important aspect in sustainability three aspects is the social aspect, and then follow by environmental aspect and in the end with economic aspect. These priorities highlighting the type of the society were the social factor is the most important and then the environmental factor and finally the economic factor. The Author interpretation about putting the environmental in foreground upon economic is that the professionals in the field of sustainability are prior the environmental issue due to their awareness about the global challenges, and the danger of continuing with the way that don't stop that environmental impact. However, the economic issue was one of the priorities as well.

5. The study demonstrated that sustainable construction practice in the Northern Iraq I poor and many actions should be taken in order to develop this situation. This could be done with two main ways; the legislations and new regulation in the building construction sectors enforce the people to apply sustainable way in construction sector. Another way is to promote the awareness about the sustainability and the benefit behind applying this system.

\section{Acknowledgement}

This research did not receive any specific grant from funding agencies in the public, commercial, or not-for-profit sectors.

\section{Refrernces}

Adams, W.M. (2006, 29-31, January). The Future of Sustainability: Re-thinking Environment and Development in the Twenty-first Century. Report presented to the IUCN Renowned Thinkers Meeting.IUCN, the world conservation union. https://portals.iucn.org/library/node/12635

Al Surf, M. S. (2014). Challenges Facing the Application of Sustainability to Housing in Saudi Arabia. Ph.D. Thesis, Queensland University of Technology, Brisbane, Queensland. Australia: Queensland University of

https://eprints.qut.edu.au/78685/

Technology.

Alizadehsalehi, S., \& Yitmen, I. (2016). The Impact of Field Data Capturing Technologies on Automated Construction Project Progress Monitoring. Procedia engineering, 161, (pp 97-103).

https://doi.org/10.1016/j.proeng.2016.08.50 $\underline{4}$

Asif, M., Muneer, T. \& Kubie, J. (2005). Sustainability analysis of window frames. Building Services Engineering Research \& Technology 26(1): 7187. https://doi.org/10.1191/0143624405bt1 18th

Castillo, R., and Chung, N. (2005). The value of sustainability. Stanford, California, USA: Center for Integrated Facility Engineering (CIFE)Department of Energy: Washington, D.C.DOE, Annual Energy Review 2000. (2001). Energy Information Administration, U.S.

Dzokoto, S.D., Dadzie, J. (2013, 12-14, August). Barriers to sustainable construction in the Ghanaian construction industry: consultants perspectives In: Laryea, S. and Agyepong, S. 
(Eds) presented on Procs 5th West Africa Built Environment Research (WABER) Conference. Accra, Ghana, 223-234. http://dx.doi.org/10.5539/isd.v7n1p134

Gunatilake, S. (2013). The Uptake and Implementation of Sustainable Construction: Transforming Policy into Practice. Ph.D. Thesis, University of Central Lancashire, Preston, England. England: University of Central Lancashire.

http://clok.uclan.ac.uk/9247/2/Gunatilake\%2 OSachie\%20Final\%20e-

Thesis\%20\%28Master\%20Copy\%29.pdf

Häkkinen, T., Belloni, K. (2011). Barriers and drivers for sustainable building, Building Research and Information, 39(3), 239-255. https://doi.org/10.1080/09613218.2011.561948

iiSBE (2009). International Initiative for a Sustainable Built Environment. [Retrieved] on $27^{\text {th }}$ Feb., 2017 from www.iisbe.org. Indicators Research, 87(2), PP: 211-221.

Liu, A. M. M., 2006. The framework underpinning conflicting keys in sustainability: harmony-intransit. Property Management, 24 (3), 219-231. https://www.emeraldinsight.com/doi/abs/10. $1108 / 02637470610660129$ ? journalCode $=p m$

McConville J. R. (2006). Applying Life Cycle Thinking to International Water and Sanitation Development Projects: An assessment tool for project managers in sustainable development work. Master thesis, Houghton, Michigan. Michigan Technological University. USA: Michigan Technological University. http://www.mtu.edu/peacecorps/programs /civil/pdfs/iennifer-mcconville-thesis-final.pdf

Nelms, C., Russel, A.D., Lence, B.J. (2005). Assessing the performance of sustainable technologies for building projects. Canadian Journal for Civil Engineering, 32, 114-128. https://doi.org/10.1080/09613210601058139

Osaily, N.Z. (2010). The key Barriers to Implementing Sustainable Construction in West Bank -Palestine. Master Thesis, Robert Kennedy College / Zurich, University of Wales UK: University of Wales. https://libserver.bethlehem.edu/webopac/r ecords/1/97084.aspx

Robichaud, L. B. and Anantatmula, V. S. (2011). Greening project management practices for sustainable construction. Journal of Management in Engineering, 27 (1), 48-57. https://ascelibrary.org/doi/10.1061/\%28ASCE \%29ME.1943-5479.0000030

Rydin,Y., Amjad, U., Moore, S., Nye, M., Withaker, M. (2006) . Sustainable Construction and Planning: The Academic Report. London
School of Economics, London, England: Centre for Environmental Policy and Governance, The LSE SusCon Project, CEPG. http://discovery.ucl.ac.uk/92248/ Sjostrom, C. and Bakens, W. (1999). CIB Agenda 21 for sustainable construction: why, how and what. Building Research and Information, 27 (6), 347-353. https://doi.org/10.1080/09613219936917 $\underline{4}$

Soderberg, N.E. , Phillips, D.L. (2015). Task Force Report: State- building in Iraqi Kurdistan. New York, United State: Institute for the Study of Human Rights, Columbia Universit. http://www.humanrightscolumbia.org/sites /default/files/pdf/pbhr_state_building_kurd istan.pdf

U.S. Green Building Council.(2006). Building Design and Construction's White Paper on Sustainability: A Report on the Green Building Movement. [Retrieved] on $4^{\text {th }}$ of March, 2017 from http://www.usglbc.org/Docs/Resources.UN -Agenda 21. (2004). New York, USA: NY.

UNEP (2003). Sustainable building and construction: facts and figures. UNEP. [Retrieved] on $3^{\text {rd }}$ of March, 2017 from: http://www.uneptie.org/media/review/vol 26no2-3/005-098.pdf

USAID (2008). Kurdistan Region Economic Development Assessment- Final Report. USA: RTI International. http://www.mop.gov.krd/resources/MoP\% 20Files/PDF\%20Files/DCC/Studies/EDA\%20R eport_English.pdf

Williams, K., Dair, C. (2007). What is stopping sustainable building in England? Barriers experienced by stakeholders in delivering sustainable developments. Sustainable development, 15(3), 135-147.

https://doi.org/10.1002/sd.308

Zainul abidin, N., Pasquire, C. L. (2005). Delivering sustainability through value management: Concept and performance overview. Engineering, Construction and Architectural Management, 12(2), pp.168 - 180. http://irep.ntu.ac.uk/id/eprint/3999/ 